\section{NC 1 CELBR and NC 2 CELBR: Early Blight and Late Blight-resistant Fresh Market Tomato Breeding Lines}

\author{
Randy G. Gardner and Dilip R. Panthee ${ }^{1}$ \\ North Carolina State University, Department of Horticultural Science, \\ Mountain Horticultural Crops Research and Extension Center, 455 \\ Research Drive, Mills River, NC 28759
}

Additional index words. early blight, late blight, Alternaria solani, Phytophthora infestans, disease resistance

NC 1 CELBR and NC 2 CELBR are determinate, large-fruited, fresh-market tomato (Solanum lycopersicum L.) breeding lines that combine moderate resistance to early blight [Alternaria solani (Ellis \& G. Martin) L.R. Jones \& Grout] with a high level of resistance to late blight [Phytophthora infestans (Montagne) Bary].

\section{Origin}

NC 1 CELBR and NC 2CELBR are sister lines developed in a long-term breeding program in North Carolina to combine early blight and late blight resistances into adapted fresh-market tomato backgrounds. The pedigree of the two breeding lines traces back to NC 215E-1(93), a large-fruited determinate line with moderate resistance to the foliage blight phase of early blight and high resistance to the stem lesion phase of early blight (Fig. 1). NC 215 E-1(93) has a complex pedigree extending back to NC EBR-1, which has moderate foliage resistance to early blight derived from the Lycopersicon hirsutum L. (currently Solanum habrochaites S. Knapp \& D.M. Spooner) source PI 126445 and NC EBR-2, which has moderate foliage resistance and a high level of stem lesion resistance to early blight derived from Campbell 1943 (Gardner, 1988). The $P h-2$ gene for late blight resistance was derived from Richter's wild tomato, and the $P h-3$ gene was derived from L. 3707, a selection of the Lycopersicon pimpinellifolium L. (currently Solanum pimpinellifolium L.) line PI 365957 obtained from the Asian Vegetable Research and Development Center (AVRDC). The $P h-2$ and $P h-3$ genes from these small-fruited sources were backcrossed into NC 215E-1(93) to develop large-fruited lines, which were then crossed to combine the $P h-2$ and $P h-3$ genes

Received for publication 31 Mar. 2010. Accepted for publication $28 \mathrm{Apr}$. 2010.

The tomato breeding program of NC State University was supported by the North Carolina Tomato Growers Association and the Hatch project of USDA.

${ }^{1}$ To whom reprint requests should be addressed; e-mail Dilip_panthee@ncsu.edu. - 2 and $P h-3$ genes combined based on field trials in 2004 and subsequent years and late blight resistances. verified by detached leaf inoculations in the growth chamber (Brusca, 2003).

\section{Description}

Both lines have a vigorous, determinate plant habit with heavy foliage cover providing good fruit protection. Leaf color is lighter green than many other tomato lines, a characteristic that has been repeatedly observed in early blight-resistant segregates derived from the Campbell 1943 source of resistance. Immature fruits are uniform, glossy, light green ( $u$ gene), and fruit pedicels are jointed. Fruits of both lines are fairly symmetrical and flattened globe to deep oblate in shape. Blossom scars are fairly smooth and well healed. Ripe fruit develop acceptable uniform red color and are firm and highly crack-resistant. Images of the fruit are available at the following web site: http://www.mountainhort. ncsu.edu/programs/tomato/releases/seedlines. $\mathrm{html}$. In addition to early blight and late blight resistances, both lines have the $V e$ gene for resistance to verticillium wilt and the $I$ and $I-2$ genes for resistance to races 1 and 2 of fusarium wilt.

NC 1 CELBR and NC 2 CELBR were tested in field plots at Waynesville and Mills River (formerly Fletcher), NC, during the 2005-2009 summer seasons for early blight and late blight resistances in non-sprayed plots. They have been tested numerous times for late blight resistance in growth chambers using detached leaf inoculations (Brusca, 2003). In a replicated trial at Waynesville in 2005 , both selections remained free of late blight under no fungicide spray conditions, whereas NC 215 E-1(93) was devastated by late blight. Both produced high yields of good-quality fruit with large size and a high

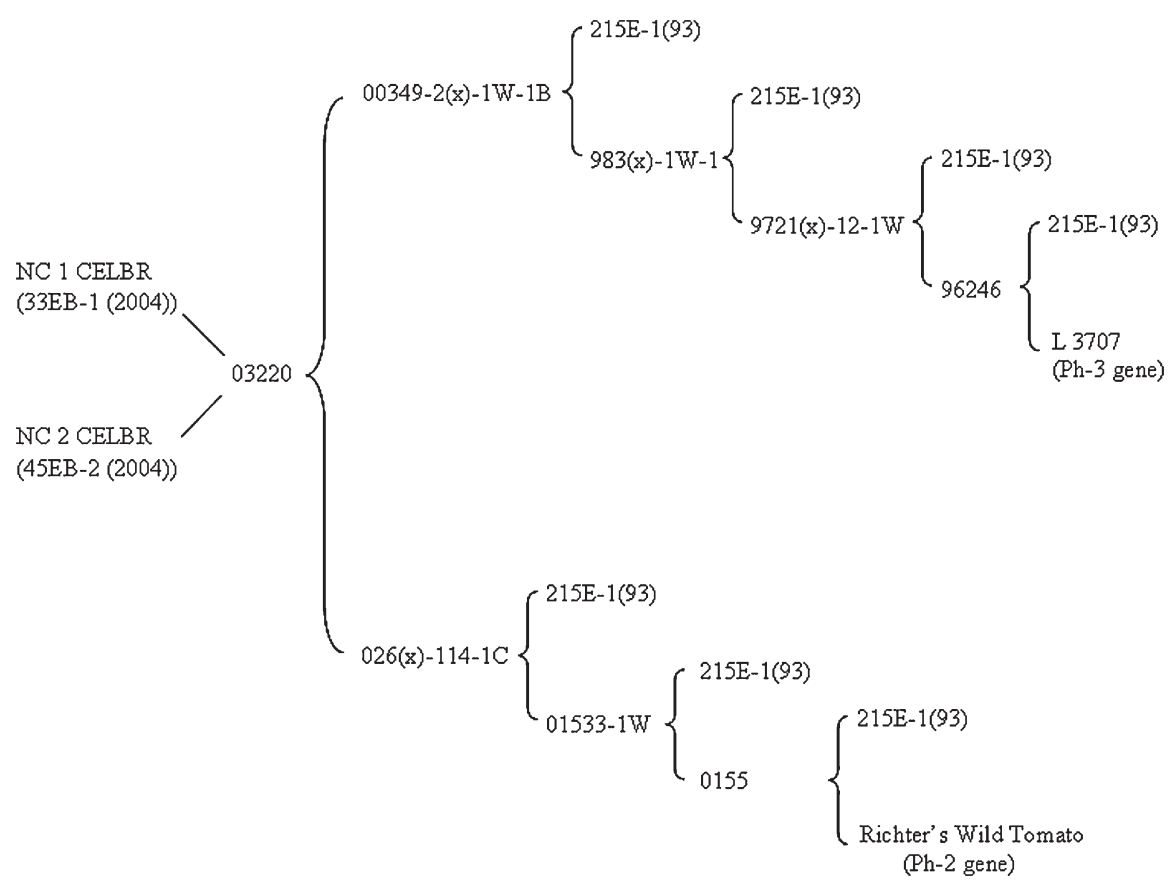

Fig. 1. Pedigrees of NC 1 CELBR and NC 2 CELBR tomato breeding lines with combined early blight and 
percent U.S. combination grade (Table 1). In two replicated vine-ripe harvest trials at Mills River in 2006 where fungicides were used for disease control, NC 1 CELBR and NC 2 CELBR did not differ from standard hybrid cultivars in total or U.S. combination grade yields (Table 2). Fruit size for both lines was smaller than for the hybrid cultivars with fruit trending to be smaller for NC 2 CELBR than for NC 1 CELBR (Table 2) and supported by the results from Waynesville (Table 1). Both lines are late in maturity as indicated by their much lower yields of vine-ripe fruit than the hybrid cultivars during the first 2 weeks of harvest in the two trials in 2006 (Table 2).

\section{Use}

NC 1 CELBR and NC 2 CELBR are the first known tomato lines that combine early blight resistance with the $P h-2$ and $P h-3$ genes for late blight resistance. They are valuable as parents in developing multiple disease-resistant $F_{1}$ hybrids and as parents in developing future tomato breeding lines with combined resistances to early blight and late blight. NC 2 CELBR was used as a parent in the $\mathrm{F}_{1}$ hybrid recently released as 'Mountain Magic'. NC 1 CELBR has shown good combining ability in $\mathrm{F}_{1}$ hybrids and is a parent in several advanced hybrids being evaluated for potential release as named cultivars. Hybrids with NC 1 CELBR and NC 2 CELBR crossed with late blight-susceptible parents are not as resistant to late blight as the resistant parent lines themselves but still provide a useful level of late blight resistance. The early blight resistance in both lines is recessive so that hybrids made with susceptible parents exhibit no resistance to early blight. Crossing the lines with early-maturing parents has resulted in hybrids with much earlier ma-

Table 1. Yield, grade, and fruit size of tomatoes grown in a late blight resistance trial at Waynesville, NC, 2005. ${ }^{\mathrm{z}}$

\begin{tabular}{lcccc}
\hline Cultivar & $\begin{array}{c}\text { Total yield } \\
\text { (ton/ha) }\end{array}$ & $\begin{array}{c}\text { U.S. combination } \\
\text { grade yield (ton/ha) }\end{array}$ & $\begin{array}{c}\text { Percent of U.S. } \\
\text { combination grade }\end{array}$ & $\begin{array}{c}\text { Avg. fruit } \\
\text { wt (gm) }\end{array}$ \\
\hline NC1CELBR & 57 & 44 & 77 & 261 \\
NC2CELBR & 43 & 36 & 84 & 235 \\
NC 215E-1 (93) & 9 & 2 & 27 & 111 \\
LSD $_{(0.05)}$ & 15 & 14 & 22 & 51 \\
\hline
\end{tabular}

${ }^{\mathrm{z}}$ Data are based on one harvest of all fruits greater than $5 \mathrm{~cm}$ in diameter. Harvested fruits of NC $215 \mathrm{E}-1$ (93) were late set fruits not yet destroyed by late blight.

LSD $=$ least significant difference.

Table 2. Performance of NE 1CELBR, NC 2CELBR and hybrid tomatoes in a vine-ripe harvest replicated trial, Mills River, NC, 2006.

\begin{tabular}{|c|c|c|c|c|c|c|c|c|}
\hline \multirow[b]{2}{*}{ Cultivar } & \multicolumn{2}{|c|}{$\begin{array}{l}\text { Total yield } \\
\text { (ton/ha) }\end{array}$} & \multicolumn{2}{|c|}{$\begin{array}{l}\text { US combination } \\
\text { yield (ton/ha) }\end{array}$} & \multicolumn{2}{|c|}{$\begin{array}{l}\text { First } 2 \text { weeks of } \\
\text { harvest (ton/ha) }\end{array}$} & \multicolumn{2}{|c|}{$\begin{array}{l}\text { Avg. fruit } \\
\text { wt (g) }\end{array}$} \\
\hline & $\begin{array}{l}\text { Early } \\
\text { trial }\end{array}$ & $\begin{array}{l}\text { Late } \\
\text { trial }\end{array}$ & $\begin{array}{c}\text { Early } \\
\text { trial }\end{array}$ & $\begin{array}{l}\text { Late } \\
\text { trial }\end{array}$ & $\begin{array}{c}\text { Early } \\
\text { trial }\end{array}$ & $\begin{array}{l}\text { Late } \\
\text { trial }\end{array}$ & $\begin{array}{l}\text { Early } \\
\text { trial }\end{array}$ & $\begin{array}{l}\text { Late } \\
\text { trial }\end{array}$ \\
\hline Mountain Spring & 79 & 127 & 42 & 88 & 43 & 31 & 312 & 281 \\
\hline Mountain Fresh & 89 & 129 & 69 & 98 & 31 & 28 & 317 & 286 \\
\hline Fla 47 & 79 & 120 & 43 & 88 & 37 & 35 & 323 & 275 \\
\hline NC1CELBR & 71 & 121 & 54 & 89 & 13 & 5 & 298 & 230 \\
\hline NC2CELBR & 79 & 107 & 55 & 81 & 17 & 7 & 284 & 207 \\
\hline $\operatorname{LSD}_{(0.05)}$ & NS & NS & NS & NS & 15 & 9 & 23 & 31 \\
\hline
\end{tabular}

LSD = least significant difference; $\mathrm{NS}=$ nonsignificant.

turity than the two lines themselves. The most useable level of late blight and early blight resistances combined in $\mathrm{F}_{1}$ hybrids will be dependent on developing suitable parental lines with the early and late blight resistances incorporated into both parents.

\section{Availability}

Distribution of seed of NC 1 CELBR and NC 2 CELBR to other breeders requires a signed seed transfer agreement, which can be downloaded with instructions for submission at the following web site: http://www. mountainhort.ncsu.edu/programs/tomato/ releases/tomato-seed-transfer-agreement.pdf.

\section{Literature Cited}

Brusca, J.P. 2003. Inheritance of tomato late blight resistance from 'Richter's Wild Tomato' and evaluation of late blight resistance gene combinations in adapted fresh market tomato backgrounds. Department of Horticultural Science. North Carolina State University, Raleigh, NC. p. 71.

Gardner, R.G. 1988. NC EBR-1 and NC EBR-2 early blight resistant tomato breeding lines. HortScience 23:779-781. 